Vol. 2, n. 3 - Edição Especial: Ciclos Formativos em Ensino de Ciências

\title{
Hoje tenho aula. Que caderno eu levo?
}

\author{
Today I have class. What notebook do I carry?
}

\author{
Rosemar Ayres dos Santos (roseayres07@gmail.com) \\ Universidade Federal da Fronteira Sul (UFFS)
}

\begin{abstract}
Resumo: A educação escolar, ao longo do tempo, sofreu inúmeras mudanças/transformações, mas, uma coisa perpassa por todo esse período e se mantém, as horas de planejamento de aulas para serem ministradas nas disciplinas escolares. E, para isso precisamos do caderno de planejamento, também, muitas vezes, denominado de diário de classe ou diário do professor. Como o próprio nome diz, é um caderno, seja de papel ou virtual, receptor das aulas planejadas a serem ministradas, nele depositamos, também, entre outras cosias, as observações/anotações durante as aulas e/ou pós-aulas, enfim, local no qual fazemos um mapeamento de tudo que necessita ser discutido em sala de aula. Assim, tem muitos registros, sejam das concepções de currículo, seja o currículo propriamente dito, sejam as metodologias de ensino, as reflexões da prática, dentre tantas possibilidades. Desse modo, nesse relato de experiência problematizarei a utilização desse documento/registro da vida em sala de aula de forma próxima a uma narrativa autobiográfica.
\end{abstract}

Palavras-chave: Ensino; Formação; Prática educativa.

Abstract: School education, over time, has undergone numerous changes/transformations, but one thing runs through this period and the hours of lesson planning to be taught in school subjects. And for this planning we need the planning notebook, also often called the class diary or the teacher's diary. As its name implies, it is a notebook, whether paper or virtual, the recipient of the planned classes to be taught, we also deposit, among other things, the observations/annotations during the classes and/or after classes, finally, place in which we map everything that needs to be discussed in the classroom. Thus, there are many records, either of curriculum conceptions, either the curriculum itself, or the teaching methodologies, the reflections of practice, among so many possibilities. Thus, in this experience report I will problematize the use of this document/record of classroom life in a way close to an autobiographical narrative.

Keywords: Teaching; Formation; Educational practice.

Recebido em: 27/08/2019

Aceito em: 10/10/2019

ISSN 2595-4520 
Vol. 2, n. 3 - Edição Especial: Ciclos Formativos em Ensino de Ciências

\section{INICIANDO O PLANEJAMENTO}

A educação escolar, ao longo do tempo, sofreu inúmeras mudanças/transformações, mas, uma coisa perpassa por todo esse período e se mantém, as longas horas de planejamento de aulas para serem ministradas nas disciplinas escolares. Contudo, o que é planejar? Vasconcellos afirma que "[...] planejar é antecipar mentalmente uma ação a ser realizada e agir de acordo com o previsto [...]" (2000, p. 35), no caso das referidas aulas esse planejamento necessita ser registrado por escrito.

Todavia, como começamos a planejar uma aula? Pelo começo? Mas, qual é o começo? Depende da intencionalidade, do discurso que se quer produzir. Pode ser mais teórico/científico, mais sociológico, uma mescla, as possibilidades são infinitas para os planos de aula.

E, para esse planejamento precisamos do caderno de planejamento, também, muitas vezes, denominado de diário de classe ou diário do professor. Como o próprio nome diz, é um caderno ${ }^{1}$, seja de papel ou virtual, receptor das aulas planejadas a serem ministradas, nele colocamos as observações/anotações durante as aulas e/ou pós-aulas, enfim, local no qual fazemos um mapeamento de tudo que necessita ser discutido em sala de aula.

Nessa perspectiva, Furtado, Brazil e Alencar (2019), ao salientarem que a construção desse tipo de caderno é uma prática comum entre os professores consideram como caderno de planejamento "os registros de aulas planejadas ou diários de reflexões que permitem ao professor executar suas ações pedagógicas em sala de aula" (p. 615).

Assim, ao revisitar um de meus tantos cadernos de planejamento, sempre cadernos de capa dura e espiral, me senti provocada a pensar sobre eles. Existem em minha vida desde os estágios curriculares supervisionados, durante a minha graduação, permaneceram quando professora da Educação Básica e continuam com a professora da Educação Superior.

${ }^{1} \mathrm{O}$ que denomino de caderno pode ser um caderno de espiral, brochura, folhas avulsas, bloco de notas, entre outros.

Recebido em: $27 / 08 / 2019$

Aceito em: 10/10/2019

ISSN 2595-4520 


\title{
Vol. 2, n. 3 - Edição Especial: Ciclos Formativos em Ensino de Ciências
}

Pode ser que durante a aula não olhe em nenhum momento para ele, que utilize outras fontes, dependendo da metodologia utilizada para a aula. Mas, ele está lá, forte, à espera, a fonte do que necessita ser dito. Nesse contexto, no relato aqui posto, meu olhar vai para essa experiência vivida. Assim, minha escrita é, de certo modo, autobiográfica (RODRÍGUEZ, 2000) e narrativa (DOMÍNGUEZ, 1996), ora se comporta como uma, ora como outra.

\section{CONTEXTUALIZANDO O LÓCUS DE PLANEJAMENTO}

A utilização de cadernos está presente em, praticamente, toda a nossa vida, desse modo, o seu manuseio se torna automático para nós, não pensamos, por exemplo, em regras de uso, mas elas nos foram ensinadas desde o início da vida escolar, que

\begin{abstract}
Para se utilizar os cadernos é preciso saber que há margens, nas quais nada deve ser escrito, que o preenchimento das folhas deve obedecer às sequências temporal e de realização das tarefas. Também devem ser aprendidas convenções de comunicação utilizadas por professores para indicar a avaliação das atividades realizadas. Assim sendo, a iniciação no uso dos cadernos prescinde a aprendizagem de um conjunto de regras, convenções e procedimentos (SANTOS; SOUZA, 2005, p. 292).
\end{abstract}

Com essas normas presentes na cultura escolar internalizadas em nós desde tenra idade, definimos o caderno a utilizar. Os por mim utilizados para planejamento de aulas tem formato grande $(27,5 \mathrm{~cm} \times 20 \mathrm{~cm})$, de 96 folhas, capa dura estampada, com espiral (popularmente dito de mola), com folhas pautadas, a primeira folha em branco, escrita dos registros em sua maioria na cor rosa, com caneta esferográfica $0.7 \mathrm{~mm}$.

Tais cadernos contém: 1- planejamento dos CCRs de estágio curricular supervisionado e dos de Prática de Ensino; 2- planejamento de aula para o mestrado; 3planejamento de atividades de pesquisa; 4- planejamento de atividades do PIBID. Embora todas essas ações estejam interligadas, precisam de organização distinta, assim, para cada uma delas um caderno diferente.

Recebido em: 27/08/2019 


\section{Vol. 2, n. 3 - Edição Especial: Ciclos Formativos em Ensino de Ciências}

Nesse sentido, autores como Vieira (2014), Soares (2019) e Furtado, Brazil e Alencar (2019) utilizam-se de cadernos de planejamento de professores como documento, uma fonte significativa de pesquisa, esses contribuem para um panorama histórico, podendo ser cruzados com outros dados daquele momento da história, como o livro didático, por exemplo. Para Vieira (2014),

[...] os cadernos de planejamento é a organização da prática a ser efetivada na sala de aula, apresenta a sequência didática que a professora planejou para a aula diária (p. 32). [...] têm como uma de suas características registrar a rotina da sala de aula (mesmo sabendo-se que nem tudo o que acontece em sala de aula em termos de ensino-aprendizagem está, obviamente, registrado nos cadernos, tanto de alunos como de professoras) (p. 33).

Assim, quanto aos distintos planejamentos no caderno, seja o currículo a ser seguido, os conceitos, os procedimentos, essas questões serão problematizados no próximo item.

\section{O QUE TEM NESSE CADERNO?}

A primeira vez que pensei em um caderno como o lócus depositário do planejamento das aulas a serem ministradas deve ter em torno de 13 anos. Foi o planejamento das aulas para desenvolver no estágio curricular supervisionado, no Curso de Física, com uma turma de estudantes do segundo ano do Ensino Médio em uma escola da rede pública de ensino.

Mas, o que tem nele? Tem muitos registros, sejam das concepções de currículo (SILVA, 2004), seja o currículo propriamente dito, os conteúdos, sejam as metodologias de ensino (DELIZOICOV; ANGOTTI; PERNAMBUCO, 2002), os instrumentos, os procedimentos, as reflexões da prática (FREIRE, 1996, 2005, 2009; FREIRE; SHOR, 1986), etc. Nele consta a síntese da prática educativa do professor, pois

[...] el profesor concibe la realidad escolar desde su particular modelo didáctico, constituido por un conjunto de creencias de diferente naturaleza: concepciones epistemológicas e ideológicas, concepciones acerca del desarrollo humano, concepciones sobre el aprendizaje y las relaciones sociales, concepciones sobre los contenidos, etc. Dicho modelo es el

Recebido em: $27 / 08 / 2019$ 
Vol. 2, n. 3 - Edição Especial: Ciclos Formativos em Ensino de Ciências

trasfondo que gula, y a la vez condiciona, toda su práctica educativa (PORLÁN; MARTÍN, 1997, p. 21).

$\mathrm{E}$, dentre essas concepções, hoje percebo que o caderno de planejamento dos estagiários que oriento em qualquer um dos quatro estágios supervisionados do Curso de Física em que sou professora é distinto dos meus, não se utilizam mais no mesmo formato, eles planejam tudo de forma online, inclusive, compartilham comigo no drive para correção e ministram suas aulas a partir desse planejamento e, por consequência, se houverem anotações, essas não acontecem durante a aula, talvez, a posteriori, no chamado diário de bordo.

Em meu tempo de graduação planejava no caderno e transcrevia tudo para o word para enviar por e-mail ao professor orientador para a correção, mas, fazia as correções por ele indicadas no caderno e o levava para a escola, independente da metodologia adotada para a aula, ela estava toda descrita no caderno, era o planejamento. Ou seja, ainda sou da geração que se apega ao de papel.

Também, nesse período e até o período em que era professora na Educação Básica, nas escolas públicas estaduais (e não apenas nelas) do Rio Grande do Sul, local em que sempre residi, havia, também, o que era denominado de caderno de chamada em papel. Nele eram registrados, além da presença dos estudantes, os conteúdos ministrados em cada aula e as notas e médias. Hoje os cadernos são digitais, disponibilizados na plataforma de gestão escolar, no início da aula o professor faz a chamada com seu smartphone ou tablet, utilizando o aplicativo Cortex, da Secretaria de Educação.

Mas, um caderno de planejamento por si só não diz tudo sobre o mundo da sala de aula e seus acontecimentos, desse modo, aliado aos planejamentos de aula, esses cadernos podem trazer as reflexões dos professores, podem estar junto com o que Pórlan e Martín (1997) nomeiam de diario del profesor. Também, em perspectiva com certa semelhança, Zabalza (2004) refere-se ao que ele denomina de diário de aula, como uma leitura da realidade das aulas, é um documento em que os professores anotam suas

Recebido em: 27/08/2019 


\section{Vol. 2, n. 3 - Edição Especial: Ciclos Formativos em Ensino de Ciências}

reflexões e impressões do que acontece em aula, para o autor trata-se de uma técnica de documentação que pode ter várias denominações como diário de aula, histórias de aula, registro de incidentes, observações de aula.

Nessa mesma linha de raciocínio, Furtado, Brazil e Alencar (2019), apoiadas em Gvirtz e Larrondo (2008) afirmam que o caderno de planejamento pode ser entendido como um "produto da cultura escolar, por este pertencer a uma instituição específica, na qual atua como dispositivo, transformando saberes, valores ou ideologias em "outra coisa"” (p. 615, grifo das autoras).

Desse modo, entendo que pode haver o diário de aula ou de bordo, conforme a denominação que cada um der, em separado ou pode ser junto com o caderno de planejamento. Não faço em separado, para mim eles são indissociáveis. Com essa perspectiva, entendo que ele é um cúmplice do professor, sabe das suas angústias, suas satisfações, seus tormentos. Sabe, também, sobre os estudantes, o currículo, as metodologias e tantas outras coisas, é um portal de memórias, de reflexões,..., testemunha da realidade vivida.

\section{CONSIDERAÇÕES}

Nessa esfera aqui problematizada, considero o caderno de planejamento como um documento de identidade, assim como a denominação dada ao currículo referido por Silva (2004). Ele identifica o professor no âmbito educativo, apresenta as questões sociais e culturais, as crenças, as intencionalidades por trás dos discursos proferidos, os ajustes curriculares, o momento histórico. Ele é pessoal e identitário.

Cabe ressaltar que essa é uma visão monóloga, muitas outras considerações devem existir, dentre as quais cada reflexão particular se encontra. Assim, isso não significa que a visão aqui exposta seja um amálgama da educação, é apenas um ponto de inflexão de uma professora formadora.

Recebido em: 27/08/2019 
Vol. 2, n. 3 - Edição Especial: Ciclos Formativos em Ensino de Ciências

\section{REFERÊNCIAS}

DELIZOICOV, Demétrio; ANGOTTI, José A. P.; PERNAMBUCO, Marta M. C. A. Ensino de Ciências: fundamentos e métodos. São Paulo: Cortez, 2002.

DOMÍNGUEZ, Antonio Garrido. El texto narrativo. Madrid: Síntesis, 1996.

FREIRE, Paulo. Pedagogia da Autonomia: saberes necessários a prática educativa. São Paulo: Paz e Terra, 1996.

FREIRE, Paulo. Pedagogia da Esperança: um reencontro com a pedagogia do oprimido. 16. Ed. Rio de Janeiro - RJ: Paz e Terra, 2009.

FREIRE, Paulo. Pedagogia do Oprimido. $48^{\mathrm{a}}$ Ed. Rio de Janeiro - RJ: Paz e Terra, 2005 .

FREIRE, Paulo; SHOR, Ira. Medo e Ousadia: o cotidiano do professor. Rio de Janeiro - RJ: Paz e Terra, 1986.

FURTADO, Alessandra Cristina; BRAZIL, Maria do Carmo; ALENCAR, Edvonete Souza de. Ensino de divisão numa escola rural de Dourados-MS (1989): uma análise do caderno de planejamento. Revista Diálogo Educacional, [S.1.], v. 19, n. 61, jul. 2019. PORLAN, R.; MARTÍN, J. EI diario del profesor: un recurso para la investigación en el aula. 4.ed. n. 6. Sevilla/ESP: Díada, 1997.

RODRÍGUEZ, Francisco. El género autobiográfico y la construcción del sujeto autorreferencial. Filología y Lingüística. v. 26, n. 2, p. 9-24, 2000.

SANTOS, Anabela Almeida Costa e; SOUZA, Marilene Proença Rebello de. Cadernos escolares: como e o que se registra no contexto escolar?. Psicologia Escolar e Educacional, v. 9, n. 2, p. 291-302. 2005.

SILVA, Tomaz Tadeu da. Documentos de identidade: uma introdução às teorias do currículo. 2. ed., 6. reimp. Belo Horizonte: Autêntica, 2004. 156p.

SOARES, Lucas Gonçalves. Cadernos de planejamento de professoras como documento histórico. RELACult, v. 05, ed. especial, p. 1-16, abr., 2019.

Recebido em: 27/08/2019

Aceito em: 10/10/2019

ISSN 2595-4520 
Vol. 2, n. 3 - Edição Especial: Ciclos Formativos em Ensino de Ciências

VASCONCELLOS, Celso dos Santos. Planejamento: projeto de ensino-aprendizagem e projeto político-pedagógico. 7. ed. São Paulo: Libertad, 2000.

VIEIRA, Cícera Marcelina. O uso de cartilhas no processo de alfabetização: um estudo a partir de cadernos de planejamento de uma professora (1983-2000). 2014. 212f. Dissertação (Mestrado em Educação) - Programa de Pós-Graduação em Educação, Faculdade de Educação, Universidade Federal de Pelotas, Pelotas, 2014.

ZABALZA, M. A. Diários de aula: um instrumento de pesquisa e desenvolvimento profissional. Porto Alegre: Artmed, 2004.

Recebido em: 27/08/2019 